\title{
Review \\ Bench-to-bedside review: High-mobility group box 1 and critical illness
}

\author{
Mitchell P Fink
}

Departments of Critical Care Medicine, Surgery and Pharmacology, University of Pittsburgh, 3550 Terrace Street, Pittsburgh, PA 15261, USA

Corresponding author: Mitchell P Fink, fink.mp@logicaltherapeutics.com

Published: 19 September 2007

This article is online at http://ccforum.com/content/11/5/229

(c) 2007 BioMed Central Ltd
Critical Care 2007, 11:229 (doi:10.1186/cc6088)

HMG1 box contains a string of 70 to 80 amino acid residues, which is folded into a characteristic, twisted, L-shaped structure [5,7]. HMGB1 facilitates the binding of several regulatory protein complexes to DNA, particularly members of the nuclear hormone-receptor family $[8,9], V(D) J$ recombinases [10], and the tumor suppressor proteins, p53 and p73 [11].

healthy controls in patients with infections and severe sepsis plasma or serum HMGB1 concentrations do not discriminate reliably between infected and uninfected critically ill patients. Nevertheless, administration of drugs that block HMGB1 secretion or of antiHMGB1 neutralizing antibodies has been shown to ameliorate organ dysfunction and/or improve survival in numerous animal models of critical illness. Because HMGB1 tends to be released relatively late in the inflammatory response (at least in animal models of endotoxemia or sepsis), this protein is an attractive target for the development of new therapeutic agents for the treatment of patients with various forms of critical illness.

\section{Introduction}

Originally identified in the early 1960 s [1], high-mobility group (HMG) proteins have been isolated and characterized from a wide variety of eukaryotic species, ranging from yeast to humans [2]. Based on the presence of characteristic functional sequences, three HMG subgroups have been identified [3-5]: the HMGB family, the HMGN family, and the HMGA family. All HMG proteins bind DNA and are soluble in $5 \%$ perchloric acid [2]. HMG proteins all have an unusual amino acid composition characterized by a high content of charged amino acids and a high content of proline [3].

The HMGB family proteins, namely HMG box 1 (HMGB1) (previously called HMG1) and HMGB2 (previously called HMG2), have molecular masses of approximately $28 \mathrm{kDa}$ and share greater than $80 \%$ amino acid sequence identity $[3,6]$. The HMGB proteins bend DNA by virtue of a conserved DNA-binding domain, the so-called HMG1 box [5]. Each

\section{The cytokine-like role of high-mobility group box 1}

In 1999, Wang and colleagues [12] identified HMGB1 as a cytokine-like mediator of lipopolysaccharide (LPS)-induced mortality in mice. Subsequently, these findings were extended by Yang and colleagues [13], who showed that HMGB1 is also a mediator of lethality in mice rendered septic by the induction of polymicrobial bacterial peritonitis. Additional studies documented that extracellular HMGB1 can promote tumor necrosis factor (TNF) release from mononuclear cells [14] and increase the permeability of Caco-2 monolayers [15].

One of the most interesting features of HMGB1 as a cytokine-like mediator of inflammation is that this protein is released much later in the inflammatory process than are the classical 'alarm-phase' cytokines, such as TNF and interleukin (IL)-1 1 . For example, in mice, injection of a bolus dose of LPS elicits a monophasic spike in circulating TNF which peaks within 60 to 90 minutes of the proinflammatory challenge and is over within 4 hours [16]. The peak in IL-1 $\beta$ concentration occurs somewhat later (that is, 4 to 6 hours after the injection of LPS) [17]. In contrast, after mice are injected with LPS, circulating levels of HMGB1 are not elevated until 16 hours after the proinflammatory stimulus but remain elevated for more than 30 hours [12]. Furthermore, treatment with neutralizing anti-HMGB1 antibodies $[12,13]$ or various pharmacological agents that block HMGB1 secretion, such

AGE = Advanced Glycation End product; AP = activator protein; DIC = disseminated intravascular coagulation; ELISA = enzyme-linked immunosorbent assay; ERK = extracellular signal-regulated kinase; GFI-1 = growth factor independence-1; HMG = high-mobility group; HMGB1 = high-mobility group box 1 ; ICU = intensive care unit; IFN- $\gamma=$ interferon-gamma; IL = interleukin; LPS = lipopolysaccharide; MAPK = mitogen-activated protein kinase; NF- $\mathrm{KB}=$ nuclear factor-kappa-B; PAMP = pathogen-associated molecular pattern; RAGE = Receptor for Advanced Glycation End products; $T L R=$ Toll-like receptor; TNF $=$ tumor necrosis factor. 
as nicotine [18] or ethyl pyruvate [19], is effective in preventing LPS- or sepsis-induced lethality, even when therapy is started 4 to 24 hours after the initiation of the disease process. Because of the delayed kinetics for release, HMGB1 is a very attractive drug target for acute, often lethal, syndromes such as severe sepsis and hemorrhagic shock because the 'treatment window' for anti-HMGB1 therapies should be longer than is the case for therapeutic agents directed at more proximal mediators of the inflammatory cascade (for example, TNF or IL-1 $\beta$ ).

\section{Passive release and active secretion of high-mobility group box 1}

Data obtained by Scaffidi and colleagues [20] supported the view that HMGB1 is passively released by necrotic, but not apoptotic, cells. This process may depend, at least in part, on activation of the enzyme PARP (poly[ADP]-ribose polymerase), which is activated as a result of DNA damage and which upon activation promotes translocation of HMGB1 from the nucleus to the cytosol [21]. In this fashion, the release of HMGB1 from necrotic tissue damaged by trauma or ischemia could serve as an endogenous 'danger signal' that alerts the immune system to the presence of injured cells $[22,23]$.

Recently, however, Jiang and colleagues [24] reported that macrophages and Jurkat $T$ cells passively release HMGB1 during the process of apoptosis. Similarly, Bell and colleagues [25] reported that Jurkat cells, U937 human monocytic cells, Panc1 (human pancreatic cancer) cells, and HeLa cells all passively release HMGB1 when apoptosis is induced by agents, such as staurosporine, etoposide, or camptothecin. Furthermore, Qin and colleagues [26] showed that incubating RAW 264.7 murine macrophage-like cells with apoptotic or necrotic macrophages or apoptotic $\mathrm{T}$ lymphocytes triggers the active secretion of HMGB1 by the RAW 264.7 cells. Thus, it seems doubtful that passive release of HMGB1 occurs only when cells die a necrotic (rather than apoptotic) death. Also, it seems doubtful that only necrotic cells are capable of eliciting HMGB1 secretion by other (viable) macrophages.

HMGB1 is actively secreted by immunostimulated macrophages [12,27-29], natural killer cells [30], plasmacytoid dendritic cells [31], pituicytes [32], and enterocytes [33]. As with members of the IL-1 family of cytokines, the primary amino acid sequence of HMGB1 lacks a signal peptide. Accordingly, secretion of HMGB1 by macrophages or monocytes presumably occurs via a nonclassical secretory pathway. Indeed, when monocytes are activated by exposure to LPS, HMGB1 relocalizes from the nucleus into cytoplasmic organelles that belong to the endolysosomal compartment [28]. Gardella and colleagues [28] reported that $65 \%$ of HMGB1 is confined to the nucleus in resting monocytes but that only $26 \%$ of HMGB1 is nuclear and $74 \%$ is associated with cytoplasmic organelles in LPS-stimulated monocytes. In activated monocytes, the transfer of HMGB1 from the nucleus to the cytoplasm is mediated by hyperacetylation of critical lysine clusters that are components of nuclear localization signals [29]. This acetylation prevents HMGB1 from interacting with the nuclear-importer protein complex, so re-entry to the nucleus is blocked. Acetylated, cytosolic HMGB1 subsequently migrates to cytoplasmic secretory vesicles. Currently, it is not known how cellular activation leads to acetylation of HMGB1.

Epithelial cells, including enterocytes, also secrete HMGB1 following immune stimulation. Kuniyasu and colleagues [34] recently reported that $\mathrm{WiDr}$ human colon cancer cells constitutively release HMGB1 into culture supernatants. In contrast, Liu and colleagues [33] observed only very low levels of HMGB1 in the media of unstimulated Caco-2 human transformed enterocyte-like cells. However, following stimulation of the cells with a mixture of TNF, IL-1 $1 \beta$, and interferon-gamma [IFN- $\gamma]$ ), there was a large increase in the amount of HMGB1 released into the culture media. Liu and colleagues [33] also showed that incubating Caco-2 cells with the synthetic Toll-like receptor (TLR) 2 ligand, FSL-1, or the TLR5 ligand, flagellin, caused a large increase in the amount of HMGB1 released into the media. Interestingly, the TLR4 agonist, LPS, failed to stimulate HGMB1 secretion by Caco-2 cells.

Data obtained by Gardella and colleagues [28] support the notion that the secretion of HMGB1 by stimulated monocytes occurs when secretory lysosomes undergo exocytosis. In contrast, secretion of HMGB1 from Caco-2 cells apparently depends on the release of exosomes into the extracellular environment upon exocytic fusion of multivesicular endosomes with the cell surface [33]. Exosomes are 30- to 90-nm membrane-bound vesicles that are secreted by numerous cell types, including reticulocytes [35], platelets [36], B lymphocytes [37], dendritic cells [38], and epithelial cells [39]. Exosomes are formed when multivesical bodies in the cytoplasm fuse with the plasma membrane, releasing the vesicles into the extracellular compartment [40].

\section{Regulation of high-mobility group box 1 mRNA expression}

HMGB1 is expressed in virtually all nucleated cells. In general, the HMGB1 gene appears to be tightly regulated, being expressed at a basal level in most cells and tissues. In proliferating tissues and actively dividing cells, there is a slight increase in expression level (approximately twofold) [41,42]. Expression of HMGB1 increases by about the same extent when estrogen-responsive breast cancer cells are treated with estrogen [43] or synchronized Chinese hamster ovary cells progress from the $G_{1}$ to the $S$ phase [44].

Transcription of the human HMGB1 gene starts at a major site located 57 nucleotides upstream from the first exonintron boundary [45]. The core promoter of the human 
HMGB1 gene lacks a TATA box and is located within the -219 to +154 region. Immediately upstream of the core promoter, there is a silencer element that contains a putative growth factor independence-1 (GFI-1)-binding site. Since GFI-1 is a known repressor [46], it is possible that GFI-1 binds to this site and represses the expression of HMGB1. Constitutive activity of this repressor may be important for maintaining HMGB1 expression at basal levels in most cells. Intron 1 is highly conserved between the human and the mouse HMGB1 genes. The region of intron 1 between +155 to +2061 contains enhancer activity, and the most potent enhancer elements are located between +1043 and +1429 . Within this region of intron 1 , there are several binding sites of putative Sp1, activator protein (AP) 1, AP4, and upstream stimulatory factor. Sp1, in particular, is known to enhance the expression of genes with TATA-less core promoters $[47,48]$ and is known to be crucial for the transcriptional regulation of IL-10 secretion by LPS-stimulated macrophages [49]. Furthermore, signaling via members of the AP1 family of transcription factors is known to be important in the transcriptional regulation of a number of genes, such as heme oxygenase-1 [50,51] and IL-18 [52], in LPS- and/or IFN- $\gamma$ stimulated macrophages.

According to Kalinina and colleagues [53], steady-state levels of HMGB1 mRNA are increased in THP-1 human promonocyte-like cells stimulated with IFN- $\gamma$ or TNF. These authors reported that TNF- or IFN- $\gamma$-induced upregulation of HMGB1 mRNA expression is not affected in THP-1 cells by pharmacological inhibition of extracellular signal-regulated kinase (ERK) 1/ERK2 mitogen-activated protein kinase (MAPK)- or PKC (protein kinase C)-dependent signaling but is inhibited by treating the cells with wortmannin, an inhibitor of PI3K (phosphatidyl inositol-3-kinase). Liu and colleagues [54] reported that incubating RAW 264.7 murine macrophage-like cells with LPS leads to increased HMGB1 mRNA expression. LPS-induced upregulation of HMGB1 mRNA expression was blocked by several pharmacological inhibitors of the JAK/STAT (Janus kinase/signal transducer and activator of transcription) signaling pathway. Increased HMGB1 mRNA expression also has been observed in animal models of acute or chronic inflammation, including collageninduced arthritis in rats [55], murine cardiac allograft rejection [56], and LPS injection in rats pretreated with ethanol [57].

\section{Role of nuclear factor-kappa-B in the regulation of high-mobility group box 1 secretion}

The TLR 4 agonist, LPS, and the cytokines TNF, IFN- $\gamma$, and TWEAK (TNF-like WEAK inducer of apoptosis) have been shown to induce HMGB1 secretion from macrophages $[12,18,27,53,58]$. Nicotine inhibits TNF- or LPS-induced HMGB1 secretion by RAW 264.7 murine macrophage-like cells [18]. Nicotine fails to inhibit LPS-induced p38, JNK, or ERK1/2 MAPK activation in RAW 264.7 cells, but nicotine does inhibit LPS-induced nuclear factor-kappa-B (NF-kB)dependent transcriptional activity [18]. These data have been interpreted as indicating that TNF- or LPS-induced HMGB1 secretion is mediated, at least in part, via activation of NF- $\kappa B$, but signaling via the three main MAPK cascades is not important [18].

Other data argue against an important role for NF- $\mathrm{KB}$ dependent signaling. In a study of TNF- or IFN- $\gamma$-stimulated THP-1 cells, Kalinina and colleagues [53] reported that HMGB1 secretion is not inhibited by the NF- $\kappa B$ inhibitor, isohelanin. Similarly, Killeen and colleagues [59] showed that treating RAW 264.7 cells with PDTC (pyrollidine diothiocarbamate), SN50 (amino acid sequence AAVALLPAVLLALLAPVORKRQKLMP), or 5-(thien-3-yl)-3-aminothiophene-2carboxamide (SC-514) blocks LPS-induced NF-KB DNA binding but fails to inhibit LPS-induced HMGB1 secretion.

\section{Receptors for high-mobility group box 1}

To date, four transmembrane proteins have been identified as potential cellular receptors for HMGB1. These proteins are

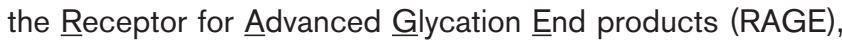
TLR2, TLR4, and syndecan-1 (CD138). It is conceivable, however, that other cell-surface receptors or even intracellular receptors participate in HMGB1-mediated cellular activation (at least in certain cell types). The intracellular protein, TLR9, also may function as a receptor for HMGB1.

RAGE, a member of the immunoglobulin superfamily of proteins, is activated by a wide variety of ligands, including products of the non-enzymatic oxidation of glucose (Advanced Glycation End products [AGEs]) [60], the amyloid- $\beta$ peptide cleavage product of $\beta$-amyloid precursor protein [61], and the $\mathrm{S} 100 /$ calgranulin family of proinflammatory cytokine-like mediators [62]. HMGB1 also binds to RAGE with high affinity $[63,64]$, and some of the proinflammatory effects of HMGB1 appear to be mediated by binding of HMGB1 to RAGE [15,65-67].

The recognition that HMGB1 is capable of activating RAGE-dependent signaling was prompted by a series of publications by Rauvala and Pihlaskari [68]. In 1987, they identified a $27-$ to $30-\mathrm{kDa}$ heparin-binding protein that promotes neurite outgrowth in rat brain neurons. Subsequently, this research group cloned this protein from a cDNA library constructed from rat brain mRNA [69]. The protein, which was called amphoterin because of its positively charged $\mathrm{N}$-terminal region and negatively charged C-terminal domain, was shown to have the same primary amino acid sequence as HMGB1 [69]. Amphoterin/ HMGB1 was shown to be localized in the cytoplasm and filopodia of neurons [69].

During the course of tissue surveys to assess RAGE distribution in vivo, it became evident that expression of the receptor occurs in early development, especially in the central nervous system where AGEs, the presumed primary ligands for RAGE, are unlikely to be present. Accordingly, these 
investigators entertained the hypothesis that AGEs might be accidental ligands for a receptor that has other functions. Toward this end, they sought to define putative natural ligands for RAGE. Starting with homogenates prepared from bovine lung tissue, protein fractions obtained using a heparinSepharose column were evaluated for RAGE-binding activity. Ultimately, two polypeptides (molecular masses of 12 and $23 \mathrm{kDa}$ ) were identified. The $23-\mathrm{kDa}$ polypeptide was identified as amphoterin/HMGB1 [63]. Moreover, authentic amphoterin/HMGB1 was shown to bind to RAGE with high affinity [63]. Subsequently, it was shown that amphoterin induces neurite outgrowth in neuroblastoma cells transfected with a plasmid encoding RAGE but not in cells transfected with a plasmid encoding a mutant RAGE missing the intracytoplasmic portion of the receptor [70].

More recently, the pathogen-associated molecular pattern (PAMP) receptors, TLR2 [71-73] and TLR4 [71-76], also have been identified as HMGB1 receptors. Nevertheless, a number of studies have shown that treatment of various cell types with anti-RAGE antibodies inhibits HMGB1-mediated effects by $50 \%$ to $100 \%[15,31,77,78]$.

Since key receptors for HMGB1, such as TLR2 and TLR4, are localized to the apical surface of enteroyctes [71,79], the observation that HMGB1 is secreted apically by intestinal epithelial cells supports the idea that release of this protein might serve an autocrine role to amplify the activation of enterocytes by other factors. This notion is supported by our previously reported observation that HMGB1 promotes activation of NK-KB in Caco-2 cells and also increases the permeability of Caco-2 monolayers [15]. To specifically test this hypothesis, Liu and colleagues [33] stimulated Caco-2 monolayers in the absence or presence of a polyclonal neutralizing anti-HMGB1 antibody added to the apical compartment of Transwell chambers. Treatment with anti-HMGB1 antibody significantly blunted the development of hyperpermeability [33]. Thus, secretion of HMGB1 may be an important positive feedback phenomenon that promotes the development of intestinal epithelial barrier dysfunction due to inflammation.

Recently, it has become apparent that highly purified HMGB1 has only minimal cytokine-like activity in vitro, whereas Escherichia coli-derived recombinant HMGB1, presumably contaminated with trace amounts of various microbial products, is more effective at triggering TNF secretion by cultured macrophages $[80,81]$. Since HMGB1 tends to avidly bind bacterial products and DNA, it is possible that the proinflammatory effects of HMGB1 are mediated not by the pure protein per se, but rather by complexes formed when the protein interacts with other proinflammatory substances [82]. This notion is supported by findings reported by Tian and colleagues [82], who showed that although HMGB1 binds to a RAGE-like man-made fusion protein (RAGE-FC), binding is much better when HMGB1 is complexed with CpG-rich oligodeoxynucleotides.
TLR9 is a PAMP receptor that is localized within cells in the endoplasmic reticulum and endosomal compartments [83,84]. TLR9 recognizes methylated (bacterial) or unmethylated (eukaryotic) CpG oligodeoxynucleotides [85]. Tian and colleagues [82] have presented data indicating that complexes of RAGE, CpG-rich oligodeoxynucleotides, and HMGB1 are transported into cells. These complexes are localized within an endosomal compartment and are physically associated with TLR9. Thus, TLR9 may be another 'HMGB1 receptor,' at least when HMGB1 is complexed with CpG-rich oligodeoxynucleotides and RAGE.

\section{High-mobility group box 1 as an inflammatory mediator implicated in the pathogenesis of critical illness}

Circulating concentrations of HMGB1 are increased in rodent models of sepsis [12,13,19,86-88] or hemorrhagic shock $[75,89]$. Furthermore, treatment with anti-HMGB1 neutralizing antibodies has been shown to ameliorate organ dysfunction and/or improve survival in rodent models of sepsis [12,13,87], hemorrhagic shock [89,90], acute pancreatitis [91], and hepatic ischemia/reperfusion injury [74]. Similarly, drugs that block HMGB1 secretion have been shown to improve survival and/or ameliorate organ dysfunction in mice subjected to cecal ligation and perforation to induce sepsis [18,19,92]. Finally, administration of authentic HMGB1 (or the B box fragment of the protein) has been shown to induce lethality and/or induce organ damage in experimental animals [12,15,93]. Thus, HMGB1 appears to fulfill a modern version of Koch's postulates for being a mediator of various forms of acute illness.

Wang and colleagues [12] reported that circulating levels of HMGB1 are increased in patients with severe sepsis, particularly among patients with a lethal form of the syndrome. Similar findings were reported by Hatada and colleagues [94], who measured plasma immunoreactive HMGB1 levels in patients with proven or suspected disseminated intravascular coagulation (DIC) by means of an enzyme-linked immunosorbent assay (ELISA) system. In that study, circulating concentrations of HMGB1 were below the detection limit in normal subjects but were moderately elevated in patients with infectious diseases, cancer, and trauma. DIC was associated with even greater plasma HMGB1 levels, and the highest HMGB1 levels were detected in patients with organ failure and nonsurvivors.

Other investigators, studying patients with infections and/or sepsis, have obtained qualitatively different findings. For example, Gaïni and colleagues [95] reported that circulating HMGB1 levels are increased (relative to healthy controls) in intensive care unit (ICU) patients with infections, sepsis, or severe sepsis (that is, sepsis with organ dysfunction). In that study, HMGB1 levels were measured by means of a commercially available ELISA kit. Importantly, these authors found that HMGB1 levels failed to discriminate between ICU patients with infections and those without infections. Thus, in 
that study at least, a high circulating level of HMGB1 appeared to be more of an indicator of 'sickness' rather than a marker of infection.

Somewhat similar findings were reported by SundenCullberg and colleagues [96], who detected persistently high serum levels of HMGB1 in patients with sepsis or septic shock but found no predictable correlation between HMGB1 concentration and severity of infection. Similarly, in a prospective study of patients with community-acquired pneumonia, Angus and colleagues [97] found that plasma HMGB1 concentrations remained elevated throughout the hospital course and did not differ between those with and without severe sepsis. In that study, HMGB1 concentrations were slightly (and statistically significantly) higher in nonsurvivors than survivors [97]. Remarkably, half of the patients who were alive at 90-day follow-up had HMGB1 concentrations greater than three times the upper 95th percentile of the range for normal controls.

Thus, in our current state of knowledge, we must conclude that even though HMGB1 is an important mediator of lethal sepsis in mice and circulating levels of HMGB1 are elevated in septic humans, there is at best a weak relationship between the magnitude of 'HMGB1-emia' and clinical prognosis. The story - at least as it stands right now - is indeed puzzling.

High circulating levels of HMGB1 also have been detected in patients with hemorrhagic shock and/or trauma. Ombrellino and colleagues [98] described a patient with high circulating levels of HMGB1 following an episode of hemorrhagic shock. This finding was confirmed by Yang and colleagues [90], who showed that circulating HMGB1 levels are significantly greater in victims of trauma with hemorrhagic shock than those measured in normal volunteers. High circulating levels of HMGB1 also have been detected during the first few days after a major surgical procedure (esophagectomy) [99]. Plasma or serum HMGB1 levels are increased in patients with acute coronary syndrome or cerebral vascular ischemia (transient ischemic attack or cerebral vascular accident) [100], human immunodeficiency virus infection [101], multiple organ failure associated with critical illness [94], acute lung injury [102], and severe acute pancreatitis [103].

All of the available clinical data regarding HMGB1 levels in plasma or serum in patients with various forms of acute or chronic illness have been obtained by measuring immunoreactive levels of the protein. Unfortunately, detecting HMGB1 by ELISA or Western blot assay fails to provide information about the functional activity of the protein. It is possible that the circulating form of HMGB1 changes over time. For example, in the first 48 hours or so after the onset of an acute infection, HMGB1 might be present as a proinflammatory mediator, whereas later on the protein might be biologically inactive (or even, potentially, anti-inflammatory). Clearly, additional clinical studies that seek to correlate immunoreactive protein levels with HMGB1-mediated biological responses are needed.

Therapeutic agents targeting high-mobility group box $\mathbf{1}$ As yet, of course, no anti-HMGB1 therapeutic is available for clinical administration to humans. Nevertheless, a number of agents have been shown to be capable of blocking HMGB1 secretion by immunostimulated cells, including various nicotinic cholinergic agonists [18,104]; stearoyl lysophosphatidylcholine [105]; ethyl pyruvate [19]; the serine protease inhibitor, nafamostat mesilate [86]; several steroid-like pigments (tanshinone I, tanshinone IIA, and cryptotanshinone) derived from a Chinese medicinal herb, danshen (Salvia miltiorrhiza) [92]; and the diuretic, ethacrynic acid, as well as other drugs that are known to be 'phase 2 enzyme' inducers [59]. Some of these pharmacological agents, as well as various polyclonal neutralizing anti-HMGB1 antibodies, have been shown to ameliorate organ dysfunction and/or improve survival in various animal models of critical illness (see above). Because the HMGB1-as-cytokine story is still less than a decade old, it probably will be several more years before any of these approaches for targeting HMGB1 will be tested in a proof-of-principle trial in human patients. However, because HMGB1 is such an attractive drug target, it seems likely that such trials eventually will be performed. Additionally, it is possible that approaches such as using hemoperfusion through a column packed with the LPSbinding agent, polymyxin B $[106,107]$, can indirectly decrease circulating levels of HMGB1 by removing the upstream stimulus for secretion of the protein.

\section{Conclusion}

One of the most important discoveries in the field of immunology during the past few years was the recognition that HMGB1 is not only a DNA-binding protein but also a proinflammatory cytokine-like protein that fulfills 'Koch's postulates' as a mediator of sepsis-induced lethality (at least in rodents). Because HMGB1 is released relatively late in the inflammatory cascade, this protein is potentially quite attractive as a novel target for new therapeutic agents designed to improve outcome for patients with sepsis or other forms of critical illness. By the same token, delineating the precise role of HMGB1 in the pathogenesis of sepsis or other acute and chronic inflammatory conditions has proven to be exceedingly complicated, and we probably are quite a few years away from knowing whether anti-HMGB1 therapeutic agents will be beneficial for treating human diseases.

\section{Competing interests}

MPF is a consultant for Critical Therapeutics, Inc (Lexington MA) and holds stock in Critical Therapeutics, Inc.

\section{References}

1. Johns EW: Studies on histones. 7. Preparative methods for histone fractions from calf thymus. Biochem J 1964, 92:55-59.

2. Aleporou-Marinou $V$, Marinou $H$, Patargias $T$ : A mini review of the high mobility group proteins of insects. Biochem Genet 
$2003,41: 291-304$

3. Goodwin GH, Sanders C, Johns EW: A new group of chromatin-associated proteins with a high content of acidic and basic amino acids. Eur J Biochem 1973, 38:14-19.

4. Bustin M, Lehn DA, Landsman D: Structural features of the HMG chromosomal proteins and their genes. Biochim Biophys Acta 1990, 1049:231-243.

5. Thomas JO, Travers AA: HMG1 and 2, and related 'architectural' DNA-binding proteins. Trends Biochem Sci 2001, 26:167-174.

6. Sanders C: A method for the fractionation of the high-mobility-group non-histome chromosomal proteins. Biochem Biophys Res Comm 1977, 78:1034-1042.

7. Bianchi ME: Prokaryotic HU and eukaryotic HMG1: a kinked relationship. Mol Microbiol 1994, 14:1-5.

8. Prendergast P, Onate SA, Christensen K, Edwards DP: Nuclear accessory factors enhance the binding of progesterone receptor to specific target DNA. J Steroid Biochem Mol Biol 1994, 48:1-13.

9. Zhang CC, Krieg S, Shapiro DJ: HMG-1 stimulates estrogen response element binding by estrogen receptor from stably transfected HeLa cells. Mol Endocrinol 1999, 13:632-643.

10. Ciubotaru M, Schatz DG: Synapsis of recombination signal sequences located in cis and DNA underwinding in V(D)J recombination. Mol Cell Biol 2004, 24:8727-8744.

11. Stros M, Muselikova-Polanska E, Pospisilova S, Strauss F: Highaffinity binding of tumor-suppressor protein p53 and HMGB1 to hemicatenated DNA loops. Biochemistry 2004, 43:72157225.

12. Wang $\mathrm{H}$, Bloom $\mathrm{O}$, Zhang $\mathrm{M}$, Vishnubhakat $\mathrm{JM}$, Ombrellino $\mathrm{M}$, Che J, Frazier A, Yang $\mathrm{H}$, Ivanova $\mathrm{S}$, Borovikova $\mathrm{L}$, et al:: HMG-1 as a late mediator of endotoxin lethality in mice. Science 1999, 285:248-251.

13. Yang H, Ochani M, Li J, Tanovic M, Harris HE, Susarla S, Ulloa L, Wang H, DiRaimo R, Czura CJ, et al.: Reversing established sepsis with antagonists of endogenous HMGB1. Proc Natl Acad Sci U S A 2004, 101:296-301.

14. Andersson $\mathrm{U}$, Wang $\mathrm{H}$, Palmblad $\mathrm{K}$, Aveberger $\mathrm{AC}$, Bloom $\mathrm{O}$, Erlandsson-Harris $\mathrm{H}$, Janson $\mathrm{A}$, Kokkola $\mathrm{R}$, Zhang $\mathrm{M}$, Yang $\mathrm{H}$, et al:: High mobility group 1 protein (HMG-1) stimulates proinflammatory cytokine synthesis in human monocytes. J Exp Med 2001, 192:565-570.

15. Sappington PL, Yang R, Yang H, Tracey KJ, Delude RL, Fink MP: HMGB1 B box increases the permeability of Caco-2 enterocytic monolayers and impairs intestinal barrier function in mice. Gastroenterology 2002, 123:790-802.

16. Zuckerman SH, Shellhaas J, Butler LD: Differential regulation of lipopolysaccharide-induced interleukin 1 and tumor necrosis factor synthesis: effects of endogenous and exogenous glucocorticoids and the role of the pituitary-adrenal axis. Eur $J$ Immunol 1989, 19:301-305.

17. Zuckerman SH, Evans GF, Butler LD: Endotoxin tolerance: independent regulation of interleukin-1 and tumor necrosis factor expression. Infect Immun 1991, 59:2774-2780.

18. Wang $\mathrm{H}$, Liao $\mathrm{H}$, Ochani $\mathrm{M}$, Justiniani $\mathrm{M}$, Lin $\mathrm{X}$, Yang L, Al-Abed $\mathrm{Y}$, Wang $\mathrm{H}$, Metz $\mathrm{C}$, Miller EJ, et al:: Cholinergic agonists inhibit HMGB1 release and improve survival in experimental sepsis. Nat Med 2004, 10:1216-1221.

19. Ulloa L, Ochani M, Yang H, Halperin D, Yang R, Czura CJ, Fink $\mathrm{MP}$, Tracey KJ: Ethyl pyruvate prevents lethality in mice with established lethal sepsis and systemic inflammation. Proc Natl Acad Sci U S A 2002, 99:12351-12356.

20. Scaffidi $P$, Misteli $T$, Bianchi ME: Release of chromatin protein HMGB1 by necrotic cells triggers inflammation. Nature 2002, 418:191-195.

21. Ditsworth D, Zong WX, Thompson CB: Activation of poly(ADP)ribose polymerase (PARP-1) induces release of the proinflammatory mediator HMGB1 from the nucleus. $\mathrm{J} \mathrm{Bio/} \mathrm{Chem}$ 2007, 282:17845-17854.

22. Matzinger $P$ : The danger model: a renewed sense of self. Science 2002, 296:301-305.

23. Rock KL, Hearn A, Chen CJ, Shi Y: Natural endogenous adjuvants. Springer Semin Immunopathol 2005, 26:231-246.

24. Jiang W, Bell CW, Pisetsky DS: The relationship between apoptosis and high mobility group protein 1 release from murine macrophages stimulated with lipopolysaccharide or polyinosinic-polycytidylic acid. J Immunol 2007, 178:64956503.
25. Bell CW, Jiang W, Reich CF, Pisetsky DS: The extracellular release of HMGB1 during apoptotic cell death. Am J Physiol Cell Physio/ 2007, 291:C1318-C1325.

26. Qin S, Wang H, Yuan R, Li H, Ochani M, Ochani K, Rosas-Ballina M, Czura CJ, Huston JM, Miller E, et al.: Role of HMGB1 in apoptosis-mediated sepsis lethality. J Exp Med 2006, 203:16371642.

27. Rendon-Mitchell B, Ochani M, Li J, Han J, Wang H, Susarla S, Czura C, Mitchell RA, Chen G, Sama AE, et al:: IFN-gamma induces high mobility group box 1 protein release partly through a TNF-dependent mechanism. J Immunol 2003, 170: 3890-3897.

28. Gardella S, Andrei C, Ferrera D, Lotti LV, Torrisi MR, Bianchi ME, Rubartelli $A$ : The nuclear protein HMGB1 is secreted by monocytes via a non-classical, vesicle-mediated secretory pathway. EMBO Rep 2002, 3:995-1001.

29. Bonaldi T, Talamo F, Scaffidi P, Perrera D, Porto A, Bachi A Rubartelli A, Agresti A, Bianchi ME: Monocytic cells hyperacetylate chromatin protein HMGB1 to redirect it towards secretion. EMBO J 2003, 22:5551-5560.

30. Semino C, Angelini G, Poggi A, Rubartelli A: NK/iDC interaction results in IL-18 secretion by DCs at the synaptic cleft followed by NK cell activation and release of the DC maturation factor HMGB1. Blood 2005, 106:609-616.

31. Dumitriu IE, Baruah $P$, Bianchi ME, Manfredi AA, Rovere-Querini P: Requirement of HMGB1 and RAGE for the maturation of human plasmacytoid dendritic cells. Eur J Immunol 2005, 35: 2184-2190.

32. Wang $\mathrm{H}$, Vishnubhakat $\mathrm{JM}$, Bloom $\mathrm{O}$, Zhang $\mathrm{M}$, Ombrellino $\mathrm{M}$, Sama A, Tracey KJ: Proinflammatory cytokines (tumor necrosis factor and interleukin 1) stimulate release of high mobility group protein-1 by pituicytes. Surgery 2002, 126:389-392.

33. Liu S, Stolz DB, Sappington PL, Macias CA, Killeen ME, Tenhunen JJ, Delude RL, Fink MP: HMGB1 is secreted by immunostimulated enterocytes and contributes to cytomix-induced hyperpermeability of Caco-2 monolayers. Am J Physiol Cell Physiol 2006, 290:C990-C999.

34. Kuniyasu H, Yano S, Sasaki T, Sasahira T, Sone S, Ohmori H: Colon cancer cell-derived high mobility group 1 /amphoterin induces growth inhibition and apoptosis in macrophages. $\mathrm{Am}$ $J$ Pathol 2005, 166:751-760.

35. Johnstone RM, Adam M, Hammond JR, Orr L, Turbide C: Vesicle formation during reticulocyte maturation. Association of plasma membrane activities with released vesicles (exosomes). J Biol Chem 1987, 262:9412-9420.

36. Heijnen HF, Debili N, Vainchencker W, Breton-Gorius J, Geuze HJ, Sixma JJ: Multivesicular bodies are an intermediate stage in the formation of platelet alpha-granules. Blood 1998, 91: 2313-2325.

37. Raposo G, Nijman HW, Stoorvogel W, Liejendekker R, Harding CV, Melief CJ, Geuze HJ: B lymphocytes secrete antigen-presenting vesicles. J Exp Med 1996, 183:1161-1172.

38. Zitvogel L, Regnault A, Lozier A, Wolfers J, Flament C, Tenza D, Ricciardi-Castagnoli P, Raposo G, Amigorena S: Eradication of established murine tumors using a novel cell-free vaccine: dendritic cell-derived exosomes. Nat Med 1998, 4:594-600.

39. van Niel G, Raposo G, Candalh C, Boussac M, Hershberg R, Cerf-Bensussan N, Heyman M: Intestinal epithelial cells secrete exosome-like vesicles. Gastroenterology 2001, 121:337-349.

40. van Niel G, Heyman M: The epithelial cell cytoskeleton and intracellular trafficking. II. Intestinal epithelial cell exosomes: perspectives on their structure and function. Am J Physiol Gastrointest Liver Physiol 2002, 283:G251-G255.

41. Wen L, Huang JK, Johnson BH, Reeck GR: A human placental cDNA clone that encodes nonhistone chromosomal protein HMG-1. Nucleic Acids Res 1989, 17:1197-1214

42. Spada F, Brunet A, Mercier Y, Renard JP, Bianchi ME, Thompson EM: High mobility group 1 (HMG1) protein in mouse preimplantation embryos. Mech Dev 1998, 76:57-66.

43. Chau KY, Lam HYP, Lee KLD: Estrogen treatment induces elevated expression of HMG1 in MCF-7 cells. Exp Cell Res 1998, 241:269-272.

44. Lee KL, Pentecost BT, D'Anna JA, Tobey RA, Gurley LR, Dixon $\mathrm{GH}$ : Characterization of cDNA sequences corresponding to three distinct HMG-1 mRNA species in line CHO Chinese hamster cells and cell cycle expression of the HMG-1 gene. Nucleic Acids Res 1987, 13:5051-5068. 
45. Lum HK, Lee KL: The human HMGB1 promoter is modulated by a silencer and an enhancer-containing intron. Biochim Biophys Acta 2001, 1520:79-84.

46. Zweidler-McKay PA, Grimes HL, Flubacher MM, Tsichlis PN: Gfi1 encodes a nuclear zinc finger protein that binds DNA and functions as a transcriptional repressor. Mol Cell Biol 1996, 16:4024-4034

47. Lee $Y$, Johnson LF: Transcriptional control elements of the rat thymidylate synthase promoter: evolutionary conservation of regulatory features. Exp Cell Res 2000, 258:53-64.

48. Chen QY, Jackson N: Human CD1D gene has TATA boxless dual promoters: an SP1-binding element determines the function of the proximal promoter. J Immunol 2004, 172:55125521.

49. Brightbill HD, Plevy SE, Modlin RL, Smale ST: A prominent role for Sp1 during lipopolysaccharide-mediated induction of the IL-10 promoter in macrophages. J Immunol 2000, 164:19401951.

50. Camhi SL, Alam J, Otterbein L, Sylvester SL, Choi AM: Induction of heme oxygenase-1 gene expression by lipopolysaccharide is mediated by AP-1 activation. Am J Respir Cell Mol Biol 1995, 13:387-398.

51. Camhi SL, Alam J, Wiegand GW, Chin BY, Choi AM: Transcriptional activation of the HO-1 gene by lipopolysaccharide is mediated by 5' distal enhancers: role of reactive oxygen intermediates and AP-1. Am J Respir Cell Mol Biol 1998, 18:226234.

52. Kim YM, Im JY, Han SH, Kang HS, Choi I: IFN-gamma up-regulates IL-18 gene expression via IFN consensus sequencebinding protein and activator protein-1 elements in macrophages. J Immuno/ 2000, 165:3198-3205.

53. Kalinina N, Agrotis A, Antropova Y, DiVitto G, Kanellakis P, Kostolias G, llyinskaya O, Tararak E, Bobik A: Increased expression of the DNA-binding cytokine HMGB1 in human atherosclerotic lesions: role of activated macrophages and cytokines. Arterioscler Thromb Vasc Biol 2005, 24:2320-2325.

54. Liu H, Yao YM, Yu Y, Dong N, Yin HN, Sheng ZY: Role of Janus kinase/signal transducer and activator of transcription pathway in regulation of expression and inflammation-promoting activity of high mobility group box protein 1 in rat peritoneal macrophages. Shock 2007, 27:55-60.

55. Palmblad K, Sundberg E, Diez M, Soderling R, Aveberger AC, Andersson U, Harris HE: Morphological characterization of intra-articular HMGB1 expression during the course of collagen-induced arthritis. Arthritis Res Ther 2007, 9:R35.

56. Huang $Y$, Yin $H$, Han J, Huang B, Xu J, Zheng F, Tan Z, Fang M, Rui $L$, Chen $D$, et al:: Extracellular hmgb1 functions as an innate immune-mediator implicated in murine cardiac allograft acute rejection. Am J Transplant 2007, 7:799-808.

57. Frost RA, Nystrom G, Burrows PV, Lang $\mathrm{CH}$ : Temporal differences in the ability of ethanol to modulate endotoxin-induced increases in inflammatory cytokines in muscle under in vivo conditions. Alcohol Clin Exp Res 2005, 29:1247-1256.

58. Chen G, Li J, Ochani M, Rendon-Mitchell B, Qiang X, Susarla S, Ulloa L, Yang H, Fan S, Goyert SM, et al.: Bacterial endotoxin stimulates macrophages to release HMGB1 partly through CD14- and TNF-dependent mechanisms. J Leukocyte Biol 2004, 76:994-1001.

59. Killeen ME, Englert JA, Stolz DB, Song M, Han Y, Delude RL, Kellum JA, Fink MP: The phase 2 enzyme inducers, ethacrynic acid, DL-sulforaphane and oltipraz, inhibit LPS-induced HMGB1 secretion by RAW 264.7 cells. J Pharmacol Exp Ther 2006, 316:1070-1079.

60. Kislinger T, Fu C, Qu W, Yan S-D, Hofmann M, Yan S-F, Pischetstrieder M, Stern D, Schmidt A-M: N(epsilon)(carboxymethyl)lysine adducts of proteins are ligands for RAGE that activate cell signalling pathways and modulate gene expression. J Biol Chem 1999, 274:31740-31749.

61. Yan S-D, Chen X, Chen M, Zhu H, Roher A, Slattery T, Zhao L, Nagashima M, Morser J, Migheli A, et al.: RAGE and amyloidbeta peptide neurotoxicity in Alzheimer's disease. Nature 1996, 382:685-691.

62. Hofmann MA, Drury S, Fu C, Qu W, Taguchi A, Lu Y, Avila C, Kambham N, Bierhaus A, Nawroth $P$, et al.: RAGE mediates a novel proinflammatory axis: a central cell surface receptor for S100/calgranulin polypeptides. Cell 1999, 97:889-901.

63. Hori O, Brett J, Slattery T, Cao R, Zhang J, Chen JX, Nagashima
M, Lundh ER, Vijay S, Nitecki D, et al.: The receptor for advanced glycation end products (RAGE) is a cellular binding site for amphoterin. Mediation of neurite outgrowth and coexpression of rage and amphoterin in the developing nervous system. J Biol Chem 1995, 270:25752-25761.

64. Taguchi A, DelToro G, Canet A, Lee D, Tanji N, Lu Y, Ingram M, Lalla E, Hofmann M, Fu J, et al.: Blockade of RAGE/amphoterin suppresses tumor growth and metastases. Nature 2000, 405: 354-360.

65. Kallijarvi J, Haltia M, Baumann $\mathrm{MH}$ : Amphoterin includes a sequence motif which is homologous to the Alzheimer's betaamyloid peptide (Abeta), forms amyloid fibrils in vitro, and binds avidly to Abeta. Biochemistry 2001, 40:10032-10037.

66. Taniguchi N, Kawahara K, Yone K, Hashiguchi T, Yamakuchi M, Goto M, Inoue K, Yamada S, ljiri K, Matsunaga S, et al.: High mobility group box chromosomal protein 1 plays a role in the pathogenesis of rheumatoid arthritis as a novel cytokine. Arthritis Rheum 2003, 48:971-981.

67. Fiuza C, Bustin M, Talwar S, Tropea M, Gerstenberger E, Shelhamer $\mathrm{JH}$, Suffredini AF: Inflammation-promoting activity of HMGB1 on human microvascular endothelial cells. Blood 2003, 101:2652-2660.

68. Rauvala H, Pihlaskari R: Isolation and some characteristics of an adhesive factor of brain that enhances neurite outgrowth in central neurons. J Biol Chem 1987, 262:16625-16635.

69. Merenmies J, Pihlaskari R, Laitinen J, Wartiovaara J, Rauvala H: $30-\mathrm{kDa}$ heparin-binding protein of brain (amphoterin) involved in neurite outgrowth. Amino acid sequence and localization in the filopodia of the advancing plasma membrane. J Biol Chem 1991, 266:16722-16729.

70. Huttunen $\mathrm{HJ}$, Fages $\mathrm{C}$, Rauvala $\mathrm{H}$ : Receptor for advanced glycation end products (RAGE)-mediated neurite outgrowth and activation of NF-kB require the cytoplasmic domain of the receptor but different downstream signaling pathways. J Biol Chem 1999, 274:19919-19924.

71. Park JS, Svetkauskaite D, He Q, Kim J-Y, Strassheim D, Ishizaka A, Abraham E: Involvement of Toll-like receptors 2 and 4 in cellular activation by high mobility group box 1 protein. $J$ Biol Chem 2004, 279:7370-7377.

72. Yu M, Wang H, Ding A, Golenbock DT, Latz E, Czura CJ, Fenton MJ, Tracey KJ, Yang H: HMGB1 signals through toll-like receptor (TLR) 4 and TLR2. Shock 2006, 26:174-179.

73. Park JS, Gamboni-Robertson F, He Q, Svetkauskaite D, Kim J-Y, Strassheim D, Sohn JW, Yamada S, Maruyama I, Banerjee A, et al:: High mobility group box 1 protein interacts with multiple Toll-like receptors. Am J Physiol Cell Physiol 2006, 290:C917C924.

74. Tsung A, Sahai R, Tanaka H, Nakao A, Fink MP, Lotze MT, Yang $\mathrm{H}$, Li J, Tracey KJ, Geller DA, et al:: The nuclear factor HMGB1 mediates hepatic injury after murine liver ischemia-reperfusion. J Exp Med 2005, 201:1135-1143.

75. Fan J, Li Y, Levy RM, Fan JJ, Hackam DJ, Vodovotz $Y$, Yang $H$, Tracey KJ, Billiar TR, Wilson MA: Hemorrhagic shock induces NAD(P)H oxidase activation in neutrophils: role of HMGB1TLR4 signaling. J Immunol 2007, 178:6573-6580.

76. Izuishi K, Tsung A, Jeyabalan G, Critchlow ND, Li J, Tracey KJ, DeMarco RA, Lotze MT, Fink MP, Geller DA, et al.: Cutting edge: high-mobility group box 1 preconditioning protects against liver ischemia-reperfusion injury. J Immunol 2006, 176:71547158.

77. Treutiger CJ, Mullins GE, Johannson AS, Rouhiainen A, Rauvala $\mathrm{HM}$, Erlandsson-Harris $\mathrm{H}$, Andersson U, Yang H, Tracey KJ, Andersson J, et al.: High mobility group $1 \mathrm{~B}$-box mediates activation of human endothelium. J Internal Med 2003, 254:375385.

78. Kokkola R, Andersson A, Mullins G, Ostberg T, Treutiger CJ, Arnold B, Nawroth P, Andersson U, Harris RA, Harris HE: RAGE is the major receptor for the proinflammatory activity of HMGB1 in rodent macrophages. Scand J Immunol 2005, 61:19.

79. Cario E, Brown D, McKee M, Lynch-Devaney K, Gerken G, Podolsky DK: Commensal-associated molecular patterns induce selective toll-like receptor-trafficking from apical membrane to cytoplasmic compartments in polarized intestinal epithelium. Am J Pathol 2002, 160:165-173.

80. Rouhiainen A, Tumova S, Valmu L, Kalkkinen N, Rauvala H: Pivotal advance: analysis of proinflammatory activity of highly 
purified eukaryotic recombinant HMGB1 (amphoterin). J Leukocyte Biol 2007, 81:49-58.

81. Zimmermann $K$, Volkel D, Pable S, Lindner T, Kramberger F, Bahrami S, Scheiflinger F: Native versus recombinant highmobility group B1 proteins: functional activity in vitro. Inflammation 2004, 28:221-229.

82. Tian J, Avalos AM, Mao SY, Chen B, Senthil K, Wu H, Parroche P, Drabic S, Golenbock D, Sirois C, et al:: Toll-like receptor 9dependent activation by DNA-containing immune complexes is mediated by HMGB1 and RAGE. Nat Immuno/ 2007, 8:487496. Erratum in: Nat Immunol 2007, 8:780.

83. Bauer S, Kirschning CJ, Häcker $H$, Redecke V, Hausmann S, Akira S, Wagner H, Lipford GB: Human TLR9 confers responsiveness to bacterial DNA via species-specific CpG motif recognition. Proc Natl Acad Sci U S A 2001, 98:9237-9242.

84. Latz E, Schoenemeyer A, Visintin A, Fitzgerald KA, Monks BG, Knetter CE, Lien E, Nilsen NJ, Espevik T, Golenbock DT: TLR9 signals after translocating from the ER to $\mathrm{CpG} D N A$ in the lysosome. Nat Immunol 2004, 5:190-198.

85. Krieg AM: Therapeutic potential of Toll-like receptor 9 activation. Nat Rev Drug Discov 2006, 5:471-484.

86. Hagiwara $\mathrm{S}$, Iwasaka $\mathrm{H}$, Matumoto $\mathrm{S}$, Noguchi T: Nafamostat mesilate inhibits high-mobility group box 1 by lipopolysaccharide stimulation in murine macrophage raw 264.7. Shock 2007, 27:429-435

87. Suda K, Kitagawa Y, Ozawa S, Saikawa Y, Ueda M, Ebina M, Yamada S, Hasimoto S, Fukata S, Abraham E, et al.: Anti-highmobility group box chromosomal protein 1 antibodies improve survival of rats with sepsis. World J Surg 2006, 30:1755-1762

88. Yin $\mathrm{K}$, Gribbin $\mathrm{E}$, Wang $\mathrm{H}$ : Interferon-gamma inhibition attenuates lethality after cecal ligation and puncture in rats: implication of high mobility group box-1. Shock 2005, 24:396-401.

89. Kim JY, Park JS, Strassheim D, Douglas I, Diaz Del Valle F, Asehnoune K, Mitra S, Kwak SH, Yamada S, Maruyama I, et al.: HMGB1 contributes to the development of acute lung injury after hemorrhage. Am J Physiol Lung Cell Mol Physiol 2005, 288:L958-965.

90. Yang R, Harada N, Mollen KP, Prince JM, Levy RM, Englert JA, Gallowitsch-Puerta M, Yang L, Yang $\mathrm{H}$, Tracey KJ, et al.: AntiHMGB1 neutralizing antibody ameliorates gut barrier dysfunction and improves survival after hemorrhagic shock. Mol Med 2006, 12:104-114.

91. Sawa H, Ueda T, Takeyama Y, Yasuda T, Shinzeki M, Nakajima T, Kuroda Y: Blockade of high mobility group box-1 protein attenuates experimental severe acute pancreatitis. World J Gastroenterol 2006, 12:7666-7670.

92. Li W, Li J, Ashok M, Wu R, Chen D, Yang L, Yang H, Tracey KJ, Wang $P$, Sama $A E$, et al.: A cardiovascular drug rescues mice from lethal sepsis by selectively attenuating a late-acting proinflammatory mediator, high mobility group box 1 . J Immunol 2007, 178:3856-3864.

93. Abraham E, Arcaroli J, Carmody A, Wang H, Tracey KJ: HMG-1 as a mediator of acute lung inflammation. J Immunol 2000, 165:2950-2954.

94. Hatada T, Wada H, Nobori T, Okabayashi K, Maruyama K, Abe Y, Uemoto S, Yamada S, Maruyama I: Plasma concentrations and importance of High Mobility Group Box protein in the prognosis of organ failure in patients with disseminated intravascular coagulation. Thromb Haemost 2005, 94:975-979.

95. Gaïni S, Pedersen SS, Koldkjær OG, Pedersen C, Møller HJ: High mobility group box-1 protein in patients with suspected community-acquired infections and sepsis: a prospective study. Crit Care 2007, 11:R32.

96. Sunden-Cullberg J, Norrby-Teglund A, Rouhianen A, Rauvala $H$, Herman G, Tracey KJ, Lee ML, Andersson J, Tokics L, Treutiger CJ: Persistent elevation of high mobility group box-1 protein (HMGB1) in patients with severe sepsis and septic shock. Crit Care Med 2005, 33:564-573.

97. Angus DC, Yang L, Kong L, Kellum JA, Delude RL, Tracey KJ, Weissfeld L, GenIMS Investigators: Circulating high-mobility group box 1 (HMGB1) concentrations are elevated in both uncomplicated pneumonia and pneumonia with severe sepsis. Crit Care Med 2007, 35:1061-1067.

98. Ombrellino $M$, Wang $H$, Ajemian MS, Talhouk A, Scher LA, Friedman SG, Tracey KJ: Increased serum concentrations of highmobility-group protein 1 in haemorrhagic shock. Lancet 1999,
354:1446-1447.

99. Suda K, Kitagawa Y, Ozawa S, Saikawa Y, Ueda M, Abraham E, Kitajima M, Ishizaka A: Serum concentrations of high-mobility group box chromosomal protein 1 before and after exposure to the surgical stress of thoracic esophagectomy: a predictor of clinical course after surgery? Dis Esophagus 2006, 19:5-9.

100. Goldstein RS, Gallowitsch-Puerta M, Yang L, Rosas-Ballina M, Huston JM, Czura CJ, Lee DC, Ward MF, Bruchfeld AN, Lesser $\mathrm{ML}$, et al:: Elevated high-mobility group box 1 levels in patients with cerebral and myocardial ischemia. Shock 2006, 26:571-574.

101. Nowak P, Barqasho B, Sonnerborg A: Elevated plasma levels of high mobility group box protein 1 in patients with HIV-1 infection. AIDS 2007, 21:869-871.

102. Ueno H, Matsuda T, Hashimoto S, Amaya F, Kitamura Y, Tanaka M, Kobayashi A, Maruyama I, Yamada S, Hasegawa N, et al.: Contributions of high mobility group box protein in experimental and clinical acute lung injury. Am J Resp Crit Care Med 2004, 170:1310-1316.

103. Yasuda T, Ueda T, Takeyama $Y$, Shinzeki M, Sawa H, Nakajima $T$, Ajiki T, Fujino Y, Suzuki Y, Kuroda Y: Significant increase of serum high-mobility group box chromosomal protein 1 levels in patients with severe acute pancreatitis. Pancreas 2006, 33: 359-363.

104. Pavlov VA, Ochani M, Yang LH, Gallowitsch-Puerta M, Ochani K, Lin X, Levi J, Parrish WR, Rosas-Ballina M, Czura CJ, et al.: Selective alpha7-nicotinic acetylcholine receptor agonist GTS-21 improves survival in murine endotoxemia and severe sepsis. Crit Care Med 2007, 35:1139-1144.

105. Chen G, Li J, Qiang X, Czura CJ, Ochani M, Ochani K, Ulloa L, Yang $\mathrm{H}$, Tracey KJ, Wang $\mathrm{P}$, et al:: Suppression of HMGB1 release by stearoyl lysophosphatidylcholine: an additional mechanism for its therapeutic effects in experimental sepsis. $J$ Lipid Res 2005, 46:623-627.

106. Sakamoto $Y$, Mashiko K, Matsumoto H, Hara $Y$, Kutsukata N, Yamamoto $Y$ : Relationship between the effect of polymyxin Bimmobilized fiber and high mobility group box-1 protein in septic shock patients. ASAIO J 2007, 53:324-328.

107. Sakamoto $Y$, Mashiko $K$, Matsumoto $H$, Hara $Y$, Kutsukata $N$, Takei K, Ueno Y, Tomita Y, Yamamoto Y: Effect of direct hemoperfusion with a polymyxin $B$ immobilized fiber column on high mobility group box-1 (HMGB-1) in severe septic shock: report of a case. ASAIO J 2007, 52:e37-e39. 